\title{
A cross-cultural perspective on musealization: the museum's reception by China and Japan in the second half of the nineteenth century
}

\author{
Chang Wan-Chen*
}

\begin{abstract}
Historically museums emerged in the West and were subsequently taken up by people in other regions of the world, including the Far East, where the museum was adopted with alacrity by Japanese and Chinese intellectuals. This article explores how China and Japan imagined museums when they first encountered them in the West. It sketches how intellectuals in these two nations began to conduct 'musealization', and suggests that the museum in China and Japan was a product of appropriation of Western formats that was, however, deeply influenced by traditional attitudes to cultural preservation and display.
\end{abstract}

Key words: Musealization, Cross-cultural perspective, Museums in Japan, Museums in China.

\section{Introduction}

Although the world is now full of museums, it is a widely acknowledged fact that museums did not begin to develop in Asia, especially in the Far East, in any systematic way until they were introduced from Western Europe in the latter half of the nineteenth century. ${ }^{1}$ Yet the Far East has had a long tradition of cultural display and preservation, and so it would be worthwhile to know how these indigenous cultural traditions influenced the way the museum, as an institution and as a way of conceptualizing, was appropriated by societies in the Far East. This raises the question of whether museums that developed in the Far East were 'contact zones' in the sense the historian James Clifford uses the term. Clifford proposes that intercultural communication potentially transforms the space of the museum itself (Clifford, 1997). Borrowing the term 'contact zone' from Mary Louise Pratt and emphasizing the following definition by Pratt, 'the space of colonial encounters, the space in which peoples geographically and historically separated come into contact with each other and establish ongoing relations' (Pratt, 1992: 6), he asserted that intercultural influences worked in both directions As such, museums, as contact zones, might also be inversions and recalibrations of power relations. His argument is a compelling one to those who work in the museum world and museum policy makers because it makes the Western museum seem less hegemonic as an institution, while suggesting considerable room for creativity on the part of non-Western cultural actors. Yet, affirmations of Clifford's argument often as not merely repeat as a kind of hopeful liturgy the utopian idea of a contact zone. For this reason, there is all the more need to explore empirically the histories of how other cultural traditions draw on Western museum concepts and institutions, and to understand, in line with these forms of reception, how they transform the museum in the process.

The article reflects on this issue by exploring how people in Japanese and Chinese cultures conducted musealization in the late nineteenth and early twentieth centuries. The word 'musealization' is a neologism gradually accepted and used since 1970 among members of the International Council of Museums' (ICOM) International Committee for Museology (ICOFOM). It refers to the process of extracting a real thing from its original, natural or cultural environment and conferring on it a new character as 'museum object' (musealia) (Mairesse, 2004: 11). ${ }^{2}$ The museum is a kind of musealized form, a possible mode through which humans establish a special relationship with their environment. This kind of special relationship is mainly established in sensory cognition (especially vision) with musealia, as well as with standpoints that maintain a certain distance from reality (i.e. what André Malraux called 'separation') (Malraux, 1965).

museum and society, Mar 2012. 10(1) 15-xx (C) 2012, Chang Wan-Chen. ISSN 1479-8360 
Because different cultures might have different ways of imagining vision or the other senses they may have different concepts and methods of preservation of cultural heritage. Therefore, scholars of museums increasingly recognize the importance of exploring museum systems from cross-cultural perspectives. There are those who criticize the West's sense of superiority about its own culture and museums (Tawadros, 1990; Simpson, 1996), while there are others who argue that 'museological-type behaviour is a long-standing, cross-cultural phenomenon' (Kreps, 2003:4). This study hopes to contribute to that discussion by looking at China and Japan when they began to encounter museums, in order to illustrate how these societies interpreted Western museum systems through their own concepts of cultural heritage.

Japan first encountered the Western museum institution when it participated in Europe's World's Fairs. ${ }^{3}$ Japan first sent a delegation (the Takeuchi delegation) to the London World Fair in 1862. In 1867, it opted to send artefacts for the first time to the World's Fair organized by Paris. Fukuzawa Yukichi (1835-1901) of the Takeuchi delegation was a figure who exercised great influence over the emergence and development of Japanese museums. The Japanese government's experience of continued participation in the World's Fairs not only advanced Japanese exchanges with the West, but also further integrated the World's Fairs systems into Japan, playing a catalytic role in the birth of the museum (Yumoto, 1996: 192). As for China, it was also during the mid-nineteenth century that young intellectuals and Qing (1644-1911) government officials, through study-abroad or diplomatic channels, came into contact with modern science and culture in Western Europe, the US and Japan, and began to consider the significance and existential value of museums from the perspectives of Chinese tradition.

\section{The connotation of Hakubutsukan and Bowuguan}

In 1862, the thirty-six members of the Takeuchi delegation set off on a diplomatic mission to six European countries, including France, Britain and Holland, in what can be said to have been the first major occasion on which Japan encountered European culture on its own initiative. Among a series of remarkable discoveries by this ambassadorial delegation, the museum institution can be said to be one of extreme importance. At its first stop, Paris, the diplomatic delegation visited the National Museum of Natural History. ${ }^{4}$ Serving as ad hoc translator for the group, Fukuzawa Yukichi translated 'yakuen' (medicinal herb garden) as 'kinjû sômokuen' (garden of fauna and flora) (Shiina, 1989: 26). The mission visited les Invalides, which houses Napoleon's tomb. Because this institution also housed a large amount of armaments, he translated it as 'bukukyoku' (weapons station) (Shiina, 1989:27). Later, after he had toured each museum, his renditions of the word 'museum' were even more varied; the word that eventually became the standard - 'hakubutsukan' or 'house of extensive things' --appeared after the visit to the British Museum, which was called 'Ryûton hakubutuskan' (London Museum) (Shiina, 1989: 29). The diplomatic delegation subsequently gradually adopted 'hakubutsukan' as the generic term for the museums they encountered and described.

The Takeuchi delegation's predicament in translating 'museum' amply illustrates the differences between Eastern and Western cultures, as well as the effort required for mutual understanding and its need to seek references from its own culture. The same phenomena can be observed in the understanding of late Qing intellectuals of 'museums' from the second half of nineteenth century, which they said were at one and the same time both 'institutions' and 'organizations'. Early Chinese translations were also extremely varied, reflecting the translators' different interpretations and points of view. The earliest related record among these comes from 1848. Xu Ji-yu (1795-1873), in Yinghuan Zhilue (1849) (The Historical Geography of the World), referred to the military and history museums of such countries as Prussia, Spain and Portugal, as 'jungongchang' (halls of military feats), and 'guwanku' (curio stores) (Ma, 1994: 29). Bin Zhuang (1804-date unknown), in Chengcha Biji (1866) (Notes on Taking a Sea Journey), recorded fifteen museums that he had visited in Europe. His travelling companion, compatriot and fellow student of museums, Zhang Deyi (1847-1918), recorded twenty museums in his Hanghai Shuqi (1866) (Strange Tales From Over the Oceans) (Ma, 1994: 29). They described the museums they encountered by reference to the things contained, for example as 'jigulou' (bone amassing buildings), 'wanzhongyuan' (gardens of everything), 'huage' (painting pavilions), 'jibaoyuan' (courtyards of treasures), and 'junqilou' (military equipment buildings). It can be seen from these early translations that Bin Zhuang's and Zhang Deyi's renderings were mainly 
based on the types of items collected in the museums that they observed. That is to say that they were either unaware that museums were a single cognitive field or that they were more concerned with describing these institutions only in terms of their appearances or in terms of the objects they contained.

Currently, scholars in Japan believe it was Fukuzawa Yukichi who first used the term 'hakubutsukan' to mean 'museum' (Shiina, 2005: 30). Chinese scholars also generally agree that China followed Japan's footsteps in adopting 'bowuguan' (literally, 'house of extensive things') (Chen, 1992: 4). It is worth noting that 'hakubutsukan' and 'bowuguan' are written with the same characters. For example, Wang Tao (1828-1897), of the reform movement of the late Qing, in his Manyou Suilu Tuji (Recalling Wanderings in Line With Records and Pictures) published in 1890, consistently used the term 'bowuguan' and, after that, all other more unusual renderings gradually disappeared. Also in China, the term 'bowuyuan' (literally 'garden of extensive things') was used, the most famous examples being the Nantong Bowuyuan (Nantong Museum), China's first museum to be founded by Chinese, and the National Palace Museum founded in $1924 .{ }^{5}$ However, with the exception of these two examples, the use of 'bowuyuan' was extremely rare. There was a similar situation in Japan. In early writings about plans for museums, the term 'hakubutsuen' (garden of extensive things, which was written with the same characters as 'bowuyuan') was used to refer to such organizations for raising natural organisms as zoos or botanical gardens, but in fact there were no institutions known as 'hakubutsuen'. In Chinese or Japanese, 'guan' or 'kan' implied a built entity while 'yuan' or 'en' implied a garden. The terms that they used to indicate the characteristics of the place, such as 'building', 'garden', 'pavilion', or 'courtyard', were those seen in Chinese architecture to refer to buildings erected mainly in parks and gardens. ${ }^{6}$

Although 'bowuguan' and 'bowuyuan' were neologisms in Chinese, the term 'bowu' (literally, 'extensive things') had a long history to be drawn upon. The term 'bowu' originally meant 'having a fine understanding of the reasons for things'. The 'bowu junzi' of the Chunqiu Zuo Zhuan (Zuo Quuming's Commentary to the Spring and Autumn Annals, date unknown, probably around the fifth century BC) and the Shiji (Historical Records) of Sima Qian (145-86 $\mathrm{BC}$ ), is someone who has a fine understanding of the reasons for things. The Bowuzhi (literally 'records of extensive things' or as it were, Records of Myriad Things), by Zhang Hua (232-300) of the Western Jin (266-316), is the first book to use 'bowu' in its title (Chen, 1992: 5). ${ }^{7}$ The 'bowu zhi shi' (personages of extensive things), first mentioned by Zhang Hua in this text, referred to figures with extensive knowledge of astronomy, geography and other fantastic things. This implication of having seen and heard much continued to be used in subsequent periods; in Xu Bowuzhi (Continued Records of Myriad Things) by Li Shi (1108-1181) of the Southern Sung Dynasty (1127-1279), Guang Bowuzhi (Records of Things Broad and Extensive), and Bowu Yaolan (Myriad Things to be Viewed) by Dong Si-zhang (1587-1628) and Gu Ying-tai (16201690), respectively, of the Ming Dynasty (1368-1644). The term 'bowu', therefore, means to have seen and heard much, to be proficient in worldly matters.

In the nineteenth century, 'bowu' mainly carried the connotation of natural history. The book Bowu Xin Bian (Treatise of Natural Philosophy) published in Chinese in 1855 by British missionary Benjamin Hobson, stationed in Macao, was an introduction to natural history. In Japan, scholars believe that this had to do with the introduction to Japan of nineteenth century books about natural history that translated 'museum' as 'hakubutsukan'. In Japan, the study of herbal medicine was influenced by China (Kurata et al, 1996: 285-286). Research for medical purposes into the herbs of the natural world in the eighteenth century combined the achievements of scholars who passionately researched Western scientific knowledge, gradually developing it as 'hakubutsugaku'. In order to conduct comparative research among collectors, scholars of Chinese herbal medicine in the late Edo period held a particularly large number of medical product gatherings or so-called 'product fairs'. These product fairs, whose purpose was to use exchanges to observe and emulate animals, plants and minerals, also formed Japan's native tradition of exhibiting before the Western European system was introduced. We can infer from this that the adoption of the term 'museum' is related to the 'natural history' connotation of 'hakubutsu' (which is written with the same characters as 'bowu') and was very likely influenced by the conceptions persons critical to the early spurring of development in museums in Japan took with them when they visited Western natural history museums. 


\section{Musealization and institutionalization of museums}

Japan vigorously westernized after the Meiji Restoration (1868), with its elites studying the contemporary governmental systems of Europe and the US, as well as museums and expositions. The World's Fairs attended by the diplomatic delegation that visited Europe also had a direct impact on Japan's museum industry. Out of commercial or political interest, each country exhibited the features of the products, machines and tools that it considered most worthy of flaunting, sending shockwaves through the Japanese delegation, but expositions in fixed places during fixed periods, bringing together different items from different places, were similar to the product fairs of Japan's Edo period. For this reason, Europeans, for the sake of museums that passed on existing knowledge, and expositions that combined the functions of enriching the state and of absorbing new knowledge, all subscribed to Japan's early concept of museums (Shiina, 2005: vi).

During Japan's Meiji period, in order to study the multi-country fair system, people who had been to Europe also in 1872 held the first government-run exposition at Tokyo's Yushima seidô (Tsuruta, 1960: 1). Several large-scale government run expositions, their exhibits and the venue, became the foundation for the subsequent establishment of a museum. This history of Japan's early establishment of museums reflects Japan's attitude of vigorous study of Europe and the US (Higuchi, 1981).

Many enlightened Japanese figures expressed their expectations of museums in writing. Typical of such figures was Fukuzawa Yukichi (1835-1901). His work, Things Western, based on his several experiences as a member of diplomatic delegations, is an important, enlightening work among studies of the West during the Meiji period. In a chapter of the book titled 'Hakubutsukan', he first described museums as 'Places established to collect and display to the people of the world products, antiquities, and rare items from all over the world, in order to enhance experience' (Fukuzawa, 2002: 48). From this definition we can see that he believed that the main function of museums was to 'enhance experience', which can be glossed as 'having educational significance'.

Next, he categorized museums into the five categories of mineralogical museums, zoological museums, zoos, botanical gardens, and medical museums (Fukuzawa, 2002: 4849). These five categories were all categories of the natural sciences. Fukuzawa did not mention such museums of the humanities as art galleries, history museums and ethnological museums. The reasons for this are most likely his own background and his experiences of visiting European and US museums.

The World's Fairs attended by the diplomatic delegation that visited Europe also had a direct impact on Japan's museum industry. Members of the Japanese delegation were shocked and awed by the products on display, even though expositions in fixed places during fixed periods, bringing together different items from different places, were similar to the product fairs of Japan's Edo period. Japanese saw a connection between expositions that combined the functions of enriching the state and of absorbing new knowledge and museums that displayed objects associated with existing knowledge. Also for this reason, Japanese scholars believe that Japan's process of creation of museums occurred in the order, 'product fairs, expositions, museums' (Shiina, 2005).

In this history of museum development and establishment during Japan's early period, one text worthy of our attention and analysis is a piece extracted by the 'Hakubutsukyoku' (Bureau of Museums) in 1872: Hakubutsukan no Shomu (Museum Affairs) (Shiina, 1989: 72 78). This text synthesized the basic thinking of the 'Hakubutsukyoku' about establishing museums. Its contents can be seen as the crowning achievement of Japan's concept of museums at this time.

In Museum Affairs, the three main purposes of establishing museums were clearly listed from the very beginning:

1. To exhibit and research animal, plant and mineral items.

2. To edit and translate books related to the three subjects and make these available to the public.

3. To open libraries to enable people to read valuable books. (Shiina, 1989: 74) 
From the perspective of today, this standpoint embodies two matters to which we should pay particular attention. First of all, at the time, as regards concepts of museum collections and exhibitions, Japan considered natural science as being most important in scope; the preservation of antiquities, cultural assets, and so forth, while they received some emphasis, were not the main focus. Also, museums and libraries (originally 'shosekikan', which literally means 'book repositories') enjoyed almost equal status, so the importance attached to the translation, availability and promotion of books was no less than that attached to the exhibition of, and research into, commodities.

The text of Museum Affairs drew concrete distinctions between the various organizations known as 'hakubutsukan' (museums), 'hakubutsuen', 'shosekikan', and 'hakubutsukyoku', and separately explained the function and role of each (Shiina, 1989: 74-78). First, 'hakubutsukan', are mainly concerned with exhibiting two kinds of items: the natural and the man-made. What are known as 'natural' are not just species from the natural world, but also items crafted from natural things, and can be further distinguished by the four categories: plants, animals, minerals and fossils. Man-made products included not only items manufactured with advanced techniques, and the exhibits seen in modern museums of industry, but also antique and handicraft everyday items.

The term, 'hakubutsuen' (garden of extensive things), bears great similarity to the frequently seen zoological and botanical gardens of today, especially as the implicit 'bowuyuan' function is not confined to exhibiting, but also emphasizes, planting and cultivating; propagating, etc., the sense of a venue for agricultural experiments, amply demonstrating the comprehensiveness of the interpretation of the Western zoological and botanical gardens. As regards 'shosekikan', as previously stated, this was the library of today. The text particularly mentions that, for places to establish 'shosekikan', it was necessary to consider dry, high land in many remote and diverse areas, which also illustrates the importance attached to the preservation of texts. 'Hakubutsukyoku' (bureaux of museums), meanwhile, were established as institutions that incorporated all three, and their responsibilities included the tasks of editing and translation of books, and the manufacture of specimens.

In China, late Qing dynasty intellectuals who served as envoys overseas, or went abroad to study, explore, or for some other purpose, encountered museums as institutions and systems in Europe, the US, and Japan. They recorded their first-hand experiences in travel writings and diaries, which became the basis of our analyses of their assessments and views of museums. To sum up, Qing era intellectuals believed that museums functioned as sites of learning and scholarship. They also assumed that museums enabled people to learn about the present by studying the past; and that museums that were scientific in nature were especially capable of enlightening visitors through processes of enquiry and explanation, thus exerted a positive effect on social progress (Sung, 1986: 47). Put simply, from this time on, Chinese intellectuals attached special value to the educational function of museums.

The emerging museums on Chinese soil at this time, however, were mainly located in the international concessions or missionary districts, and they served to provide Westerners in the Far East with a platform from which to conduct research into natural history or ethnology. These museums engaged in only limited interaction with Chinese people, and did not inspire the public of China to reflect on museums. The Museum of Natural History, founded in 1868, for example, in Sikowei, Shanghai, by the French Catholic, Pierre Marie Heude (1836-1902), was a notable museum of natural history, which collected specimens from the natural world. It was expanded in 1920 and became the museum at Aurora University (Chen, 1992: 14-15).

If the aforementioned Aurora Museum was a base for Europeans in China conducting explorations of natural resources, then the Nantong Bowuyuan (Nantong Museum), founded in 1905 by late Qing Chinese intellectual and industrialist, Zhang Jian (1853-1926), was a museum rooted in the patriotic cause. Zhang Jian had already founded China's first teacher training school (Nantong Teachers College) in 1902, and whilst in Japan on an exploratory trip in 1903, was greatly inspired by his visit.

Not the only case of its kind, Zhang Jian's concept of museums also incorporated a strong necessity for the existence of libraries. This echoes the above-mentioned Museum Affairs. In 1904, Zhang Jian wrote Guyue cangshulou ji (Record of the Ancient Yue Book Storage Building), praising the establishment and public nature of the building (Li \& Zhang, 
1982: 110-111). The Ancient Yue Book Storage Building is located near Shaoxing, Zhejiang, and was built by Xu Shu-lan (1837-1902) in 1900. In 1904, this building was formerly opened, and was seen as the first modern public library in Chinese history and different from traditional, private book collections. It is worth mentioning that the Ancient Yue Book Storage Building possessed museum functions. Clause Six of its regulations states that the institution must, for the purposes of scientific research, collect physics and chemistry instruments and machines, as well as specimens of all kinds of animals and plants as props for the books. In 1905, Zhang Jian called for the establishment in the capital of a 'bolanguan' (place for extensive viewing), combining a museum and library (Cao \& Yang, 1994: 272). He felt that this type of organization could completely preserve heritage institutions and also serve as a model for all localities throughout the country, providing support for school education. To put it another way, his expectations for museums, with libraries added to them, lay in their educational functions and the fact that through education the country could be invigorated. It was still, therefore, a patriotic way of thinking.

Because Zhang Jian's idea was not adopted by the Qing government, he returned to his hometown of Nantong and established the Nantong Museum. The contents of this institution's collection included natural science specimens as well as artefacts; it was a comprehensive museum, and a museum that was integrated with a library as well as university education (Wang, 1990: 78-83). The importance he attached to libraries and book collecting also prompted him in 1912 to establish Nantong Library, completing the ideal of the 'bolanguan'. Zhang Jian was mainly concerned with using the museum to preserve 'the storied treasures of the empire' as well as 'sharing the empire' as a service to educated persons outside China (Jia, 1991: 79-80). This is also to say that China's emphasis on museum education in the early days was an emphasis on those aspects of education that can save a nation, which can inspire important functions for the flourishing of a nation.

In 1903, Zhang Jian wrote Guojia bowuguan tushuguan guihua tiaoyi (Suggestions on Planning for National Libraries and Museums), in which he again appealed to the government to build combined museum-library cultural institutions (Li \& Zhang, 1982: 284). Although there was no formal response to his appeal, statistics show that, among the thirteen museums of the early years of the Republic of China, eight had libraries attached to them, from which we can see that, in the early years in China, there was indeed an intimate link between museums and libraries. (Ni, 2007: 90).

As stated above, the Western museum institution connotes Western society's use of a set of integral norms, standards and value systems to conduct 'musealization'. Through the process of selection, being treated as treasure, and exhibited \% which is to say, being preserved ex situ $^{-}$the status of an object changes; it becomes a physical or non-physical testament to human beings and their environment, a resource for research and exhibition, thus gaining a special cultural character.

Musealization transcends the simple logic of collecting; it is a tradition belonging fundamentally to the discoveries of rational thought and modern science. Objects that serve as carriers of information, after being musealized, become the core of museum science activities. This represents the development since the Renaissance in the activity of investigation, through sensory perception, of reality and the research of actual elements of experience. This kind of scientific vision restricted objectivity as regards items, and repetitive study: namely in the gaining of ideas from objects, the opening up of the surface of an object, to get at its intrinsic significance. Also for this reason, the work of musealization must be perfected by means of important museum activities. These museum activities include: preservation (including selection, collection, management and conservation), research, and communication (including exhibition, publication, and all forms of activities promoting education). As regards the preservation and research of items to which museums attach value, libraries have a long history in the West, and the two have historically often played a mutually complementary developmental role. The combining of the two shows that there is a clear division of roles in the different sources of knowledge about objects on the one hand and texts on the other (Schaer, 1993: 35).

The approach that both Japan and China strove hard to imitate during the latter half of the nineteenth century was precisely the practice of musealization as described above. They did so by planning particular buildings or garden areas, establishing specific standards for 
classifying and selecting items, to set up systems and institutions conforming to the concept of the classic museum.

From the perspective of the social dimension of museums, Western civilization was based on the establishment of museums and the diverse activities practiced inside them. They developed the preservation of cultural heritage and the construction of scientific knowledge, and became important venues for mass education. Intellectuals and officials in China and Japan from the mid-nineteenth century onwards, however, did not ignore the public nature of museums in Western society. Yukichi Fukuzawa stressed the museum's educational function and vigorously promoted the Meiji government's policy of building museums. As regards Chinese intellectuals towards the end of the Qing, with China's long-term weakness and stagnation and the European powers competing to invade, the museum presented a window on advanced Western scientific and technological development and the progress of civilization. They admired the reasons why the West built museums and hoped that China would build her own museums. Very appropriately, moreover, the reason why they hoped China could build her own museums lay in their view of museums as tools for educating people and developing a function of strengthening and enriching a weak China. We can also see, however, that the Chinese and Japanese concept during the early period of museums, under the embrace of the Western system, still maintained the traditional emphasis on preservation and collection.

\section{Return to a preservation of heritage without a tangible collection}

From the perspective of the collection activities that are central to the museum's function, as regards the preservation of precious or rare objects, display methods for pure ostentation or for religious purposes were not alien to Far Eastern cultural traditions. The Shôsôin in Nara, Japan, has since the eighth century AD preserved the precious items with which the Emperor Shômu supported Tôdaiji, and remains intact to this day, a classic treasure trove (Bazin, 1967: 29). China's emperors over the centuries had no lack of enthusiasm for collecting and preserving records of their collections. The contents of the creation that is the collection of Huizong (10821135) of the Northern Sung (960-1127), for example, range from ancient bells, engraved sacrificial vessels and utensils, Three Dynasties metal and stone ware, jade implements, the painting and calligraphy of many households, and the sheer effort of actively collecting such items bequeathed by the ancients (Chang, 1998). Although she did not lack collections of either famous emperors or private persons, however, China did not advance to the attachment of value to the physical preservation and perpetual passing down of items, but turned a conceptualized preservation into two-dimensional symbolic records. In around 1120, Huizong ordered that pictorial records ${ }^{-}$namely the Xuanhe Shupu (Xuan He Book List), Xuanhe Huapu (Xuan He Painting List), and Xuanhe Bogu Tu (Xuan He Illustrations of Myriad Ancient Things) $\%$ be made of his books and bronze ware. The former two works both contain brief general discussions, introductions to the lives of the artists, item names, notes on technique, and commentary, but not actual images. As far as the Xuanhe Bogu Tu is concerned, it continued the existing, fashionable, Northern Sung tradition of research into metal and stone ware. ${ }^{8}$ In these works, we witness Chinese culture's esteem for written symbols flourishing within substantive objects. Bronze ware even earned the research emphasis of Northern Sung scholars precisely because of its function as a bearer of inscriptions.

The literary and pictorial artefacts and treasures that Huizong painstakingly collected throughout his life were comprehensively ransacked when the Jin invaded the south, but this is not the only instance in Chinese history of cultural assets incurring tragedy. Wang Shizhen (1526-1590), in Yanzhou Sibu Gao (1577) (Drafts From the Four Branches of Learning by the Recluse of Yangzhou), suggested that art has six tragedies, among which figures the vandalism of the Jingkang Era (1126-1127) (Chen, 1989: 96-97). In China, cultural assets have time and again suffered dispersal, and this is reflected in many writings. Indeed, Zhou Hui (1126-date unknown), of the early years of the Southern Sung, believed that, 'To assemble is inevitably to disperse; it's the law of nature' (Zhou, 1994: 136). Similarly, Li Jian (about 1045-1105) of the Northern Sung, in Luoyang Mingyuanji (The Famous Gardens of Luoyang), argued that the war and chaos involved in changes of empire in China were a primary reason why Chinese culture was unable over the long-term, or systematically, to preserve material culture. But what we must 
also further consider is whether this kind of environment also caused collectors or historians all the more to stress the cultural implications or symbolic significance of things and not to strive for their long-term preservation. In the aforementioned example of Huizong, by means of written or pictorial records, the spiritual value of cultural assets has been extracted and, indeed, preserved. Pierre Ryckmans (1989:810) believed that, through characters, especially characters on ancient relics, intellectuals were able to gain comfort from ancient glory. Robert Harrist (1993: 210) has also pointed out that, in Chinese culture, the preservation of the material nature of things is not of great importance, unless such things have gained cultural significance through the writing of characters.

Through the method whereby characters carry the cultural significance of the object and, therefore, weaken the importance of its material nature, we can also see the utilization of various exhibition techniques. Masao Yamaguchi (1991:64-66) illustrated traditional Japanese display techniques (mitate) and, through formalized scenery (such as bonsai), made the viewer associate it with another famous scene (such as a scene of Mt. Fuji) possibly existing in nature (such as the Eight Scenic Spots on the Xiang River). This kind of approach is also seen in China, especially in garden designs. One example is the use of Dongting Lake's 'Eight Scenic Spots on the Xiang River' as a metaphor for the fondness for designing man-made lakes (Berque, 1995: 90-94). Because the mitate Eight Scenic Spots usually did not use material from Dongting Lake, garden tourists did not have to experience a tour of that lake, but everyone understood the reference made by the scenery in question.

In both China and Japan, to 'name' is to perform a critical act. By 'naming', a person can express his literary achievements, philosophical concepts, even his political position, and the carrier of the characters becomes a kind of tool for communication. To give an example once again from gardens, both Chinese and Japanese gardens attached great importance to the act of naming, not just the naming of the garden but also the naming of the pavilions, terraces and other constructions and scenery within the garden. Naming not only expressed a person's talent and emotion through the use of plaques, stele or poetry to identify the sights of the garden, but also, through extended meaning, consummated the symbolism of the garden. Harrist (1993) gave the example Duleyuan (Garden of Solitary Joy) of Sima Guang (1019-1086) of the Northern Sung to illustrate the significance of naming as regards gardens. Through the naming of each scenic spot, the owner of the garden could take a historic philosopher as the target for his efforts. In the process of conversing with the ancients, Sima Guang placed himself within the flow of history, viewing himself as a part of history. Visitors to the Duleyuan, moreover, can experience the owner's intentions. Craig Clunas also argued that the Chinese tradition had attached as much importance to the material nature of things as to their essence; this 'is possible because there has been no challenge to the idea of the "essence" of a Chinese garden, which privileges continuing fragments of literary discourse over the contingencies of vegetal decay' (Clunas, 1996: 31). To put it another way, the naming of gardens and its implied significance lies in the function of transmitting current and future culture by simultaneously echoing historical allusions and achieving connections with the past.

In Europe, especially since the sixteenth century, there have been many examples of collections being recorded in pictorial and even published forms. Francesco Calzolari, of the seventeenth century, and Caspar Friederich Neickel of the eighteenth century, for example, compared actual curio collections through the composition of pictorial records (Deloche, 2004: 41). The Paper Museum of the earlier Roman collector, Cassiano dal Pozzo (1588-1657), recorded in pictures more than 7000 sketches, watercolours and woodblocks. Its contents touched on the categories of what are today known as natural science (palaeontology, zoology, botany, mycology) and anthropology (myths, custom, fables and appliances), fully demonstrating its spirit of seeking to explore the world (Deloche, 2004: 41-42).

What Dutch doctor, Samuel Quiccheberg (1529-1567), displayed in his well-known work, Inscription ou titres du théâtre immense, not only continued the tradition of interpretation through encyclopaedic organization of one's world (both physical and spiritual), but also lay in providing substantive collection category planning so that the term, 'scientific', displayed a certain logic, an initial model with modern museological character (Brout 2004). What Inscription ou titres du théâtre immense showed was extreme self-assertiveness, like a gesture of primogeniture. As the Creation emphasizing the world and its richness, with his special 
organization and planning, Quiccheberg can really be said to have initiated from private European collecting a pivotal period for museum institution. The classification principles that he established, although very distant from today's scientific research, still raised structures well worthy of consideration for museums that were to develop subsequently. The difference with China was that the modern activities of subsequent European museums would increasingly emphasize the viewing of objects; the collected items ${ }^{-}$rather than their innate significance became the objects of research. Here, we can see marked differences between Chinese and Western culture since the Renaissance in the West, and differently prioritized strategies in terms of concepts of cultural assets, and methods of preservation. The former preferred in the first instance to guarantee onward transmission through reproduction in pictures and publications, while the latter stuck to the conservation and preservation of authentic items by guaranteeing their inherent import through constant analysis.

The ambition to name all things and to sort them into a general written list using an ordered rationale was indeed the purpose of the Western museum from the seventeenth century onwards. As far as Quiccheberg was concerned, there was only one direction in which people could be led forward in the immense labyrinth that is knowledge. Quiccheberg's method was to invoke a kind of symbolic vocabulary, using symbols to replace items for ease of operations. There were similarities in the methods of compilation of the encyclopaedias such as the Yongle Dadian (Yongle Encyclopaedia), and the Gujin Tushu Jichen (Kangxi Imperial Encyclopaedia) of later periods in China. With the encyclopaedias of the eighteenth century, however, Denis Diderot (1713-1784) simply adopted the juxtaposition of images and text, using a sort of substantive sketch to introduce each item informatively.

\section{Conclusion}

Although Far Eastern cultures absorbed the Western museum system with alacrity in the second half of the nineteenth century, their own ideas about cultural preservation and their concepts of display influenced their understanding of this system. From research on the origins of the characters 'bo' and 'wu', we discover that Japan and China, in the second half of the nineteenth century, thought of museums in relationship to collections of natural history. This is revealed in the original connotation of the meaning of the word 'bowu' as 'all the world's living things'. Combined with this was also a longstanding tradition of the preservation and passing on of cultural heritage, in which less importance was attached to the material nature of things than to their cultural significance. The above orientations in forms of cultural collections and records, display techniques, garden designs and values, all clearly reflect the degree of importance attached to the non-material. In general, the object was not assumed to stand alone, to be self-explanatory. Understanding or knowledge of the myriad things in the human-made or natural world was not gained through the preservation or research of 'actual objects' with 'evidentiary' value, but always through written records or alternative objects transforming their meaning and circulating, spreading. This may also illustrate a fundamental reason why Western 'museums' failed, after all, to appear spontaneously in the Far East.

In the second half of the nineteenth century, when Japan and China were studying the Western museum system, we see on the one hand how the two countries consciously saw museums as symbols of the advanced civilization of the West, and also expected the establishment of museums to compensate for the inadequacy of formal school education, to develop knowledge among the people and place the nation on a path towards prosperity and power. Chinese intellectuals of the late Qing, in particular, viewed museums as an element of the great ideal of saving the nation through education. This view inevitably exaggerated the public role of museums and showed the utilitarian nature of museums as perceived by the leaders of China and Japan.

On the other hand, the two countries, in conceiving the early period of modern museums, expressed the design ideal of combined museum-libraries. Behind this ideal lay the value traditionally attached to books in the Far East. In the traditional view, books are carriers of text; the emphasis of traditional book collections was still on the non-material phenomenon that is text. When the preservation and collection of books enters the overall scheme of museums, however, the book becomes no longer a mere carrier of text but, in line with the introduction of Western systems and concepts, is itself an item in a collection. 
Modern museums should be seen as one of the numerous forms in which cultural assets are bequeathed. Today, they continue to perform a pivotal, indeed 'mainstream', role. But institutionalized museums, be they in the East or the West, have never been the only means of preservation of cultural assets. In the future, moreover, they will continue to be challenged by other forms.

Received: 14 April, 2011

Finally Accepted 30 April, 2012

\section{Acknowledgments}

I would like to thank Professor Eric Gable and three anonymous reviewers for the comments and suggestions.

\section{Endnotes}

1 What this article calls an 'institution' refers to the social structure with the import of the museum, organized and created by mankind in order to establish 'sensible relations' with objects. It is not simply an establishment having a certain substantive architecture.

2 'Real things', refers to items that are original in character, not a model, image or any other substitute item. On the basis of their nature and the value that people confer on them, they may be artefacts, handmade goods, or specimens. 'Musealia', (French: muséalie. English: musealium or musealia) is also a neologism of museology. Peter Van Mensch believes that 'musealia' are items that have been decontextualized and placed in museums (Cameron, 1968; Van Mensch, 1992; Mairesse, 2002).

3 For further discussion of development and displays of World's Fairs, see, for example, Greenhalgh, 1988.

4 National Museum of Natural History (in French, Musée national d'histoire naturelle), Paris, was founded in 1793. It had previously - from 1635 - housed the medicinal herb garden of French kings. Within the grounds were display areas in the fields of botany, zoology, geology, mineralogy, anatomy, and palaeontology. It could be said to be a general museum of natural science.

5 For the discussion of National Palace Museum's history and collections, see Hamlish, 2000.

6 For the references to Chinese gardens, see Osvald, 1949; Keswick, 1980.

7 The Bowuzhi comprised ten volumes, and it contained information about landscape and geography, tales of historic figures, strange vegetation, insects, fish, birds and beasts, ancient fairy tales and legends, even grotesque, ridiculous records of supernatural places; it was nothing if not comprehensive (Zhang, 1987).

8 The study of metal and stones during the Northern Sung meant studying the knowledge contained in inscriptions on bronze and stoneware. Learned people of the Northern Sung discussed history by studying metal and stones; so bronze ware was seen as carriers of ancient characters rather than, as today, as works of art.

9 This book has an extremely lengthy name. The designation, Inscription ou titres du théâtre immense, is the preeminent one and, therefore, the abbreviated form is generally used to refer to this work. It was first published in 1565 by Adam Berg of Munich. For a rare, complete French translation, see Brout, 2004. 


\section{References}

Bazin, G. (1967) The Museum Age, Brussels: Desoer

Berque, A. (1995) Les Raisons du Paysage - de la Chine Antique aux Environnements de Synthèse (The Reasons for Landscapes - from Ancient China to Environments of Synthesis), Paris: Hazan

Brout, N. (2004) 'Samuel Quiccheberg. Inscriptions ou titres immense (Samuel Quiccheber. Inscriptions or Immense Titles)', in François Mairesse (dir) RTBF 50 ans. L'extraordinaire Jardin de la Mémoire, 81-135, Morlanwelz: Musée royal de Mariemont

Cameron, D. (1968) 'The Museum as a communication system and implications for museum education', Curator, 11, 33-40

Cao, C.-P. \& Yang, T. (1994) Zhang Jian quanji (Complete Works of Zhang Jian), Nanjing: Jiangsu guji chubanshe

Chang, W.-C. (1998) 'Tan Wenwu Shoucang Yu Wenhua Chuancheng - Jianlun Sung Huizong Shoucang (On Collections of Artefacts and Cultural Transmission)', Guoli Lishi Bowuguan Xuebao 9, 51-75 (in Chinese)

Chen, D.-Y. (1989) Zhongguo Wenhua Shi (History of Chinese Culture), Taipei: Shijie Shuju (in Chinese)

Chen, Y. (1992) 'Zhonguo Bowuguan Zhi Yuanqi (The Origin of Chinese Museums)', Bowu Jikan, 1(4) 3-19 (in Chinese)

Clifford, J. (1997) 'Museums as Contact Zones', in Routes: Travel and Translation in the Late Twentieth Century, Cambridge: Harvard University Press, 188-219

Clunas, C. (1996) Fruitful Sites - Garden Culture in Ming Dynasty China, London: Reaktion Books

Deloche, B. (2004) 'Les contours du musée virtuel (The Outlines of the Virtual Museum)', in François Mairesse (dir) RTBF 50 ans. L'extraordinaire Jardin de la Mémoire, 35-50, Morlanwelz: Musée royal de Mariemont.

Fukuzawa Y. (2002) Fukuzawa Yukichi Chosakushû Daiikkan (The Works of Fukuzawa Yukichi, Volume One), Tokyo: Keio Gijuku Daigaku Shuppansha (in Japanese)

Greenhalgh, P. (1988) Ephemeral Vistas. The Expositions Universelles, Great Exhibitions and World's Fairs, 1851-1939, Manchester: Manchester University Press

Hamlish, T. (2000) 'Global Culture, Modern Heritage. Re-membering the Chinese Imperial Collections', in: Susan A. Crane (ed) Museums and Memory, 137-158, Stanford: Stanford University Press

Harrist, R. E. (1993) 'Site names and their meanings in the Garden of Solitary Enjoyment', Journal of Garden History, 13(4) 199-212

Higuchi, H. (1981) Hakubutsukan kôza vol. 2, Nihon to seikai no hakubutsukanshi (Lectures in Museology vol. 2, The History of the Museums of Japan and the World), Tôkyô: Yûzankaku (in Japanese)

Jia J.-M. (1991) 'Bowuguan jiaoyu zai zhongguo de zaoqi renshi yu shijian' (The early understanding and practices of museum education in China), Bowuguanxue Jikan, 5(4) 77-84 (in Chinese) 
Keswick, M. (1980) The Chinese Garden - History, Art \& Architecture, London: Rizzoli

Kreps, C. F. (2003) Liberating Culture. Cross-Cultural Perspectives on Museums, Curation, and Heritage Preservation, London \& New York: Routledge

Kurata, K. (et al) (1996) Hakubutsukangaku jiten (Encyclopedia of Museology), Tokyo: Tokyodô

Li, X.-M., 一 ÿE 4-ú Zhang, S.-H. (1982) Zhongguo gudai cangshu yu jindai tushuguan shiliao (Collection of books in Ancient China and libraries in Modern Time), Beijing: Zhonghua shuju.

Ma, J.-X. (1994) Bowuguanxue Tonglun (General Museology), Chengdu: Sichuan DaxueChubanshe (in Chinese)

Mairesse, F. (2002) 'Muséologie et présentation: où sont les vraies choses? (Museology and presentation: where are the real things?)', ICOFOM Study Series, 33b, 62-68

Mairesse, F. (2004) 'La muséalisation du monde (The musealization of the world)', in François Mairesse (dir) RTBF 50 ans. L'extraordinaire Jardin de la Mémoire, 11-34, Morlanwelz : Musée royal de Mariemont

Malraux, A. (1965) Le Musée Imaginaire (The Museum Without Walls), Paris: Gallimard

$\mathrm{Ni}, \mathrm{Y} .-\mathrm{Z} .,(2007)$ 'Zhang Jian he Nantong tushuguan' (Zhang Jian and Nantong Museum), Guojia tushuguan xuekan, 62, 89-92 (in Chinese)

Osvald, S. (1949) Gardens of China, New York: The Ronald Press Company

Pratt, M. L. (1992) Imperial Eyes: Travel Writing and Transculturation, London \& New York: Routledge

Ryckmans, P. (1989) 'The Chinese Attitude Toward the Past', in Irving Lavin (ed) World Art, Themes of Unity and Diversity, Acts of the $26^{\text {th }}$ International Congress of the History of Art, Vol. 3, 809-812, Pennsylvania: The Pennsylvania State University Press

Schaer, R. (1993) L'invention des Musées, Paris: Gallimard

Shiina, N. (1989) Meiji Hakubutsukan Koto Hajime (The Beginnings of Museums in Meiji Period), Kyoto: Sibunkaku (in Japanese)

Shiina, N. (2005) Nihon Hakubutsukan Seiritsushi - Hakurankai Kara Hakubutzukan E (The History of the Establishment of Japanese Museums - from World's Fairs to Museums), Tokyo: Yûsankaku (in Japanese)

Simpson, M. G. (1996) Making Representations. Museums in the Post-Colonial Era, London \& New York: Routledge

Sung B.-Y. (1986) Bowuguanxue jichu zhishi (The Basic Knowledge of Museology), Beijing: Zhongguo nongye bowuguan (in Chinese)

Tawadros, G. (1990) 'Is the past a foreign country?', Museum Journal, 90(9) 30-31

Tsuruta, S. (1960) 'Museum Administration in Japan', in Japanese National Commission for UNESCO (ed) Museums in Japan, 1-3, Kasai Publishing \& Printing

Van Mensch, P. (1992) Towards a Methodology of Museology, University of Zagreb, Faculty of Philosophy, PhD Thesis 
Wang H.-J. (1990) Zhongguo bowuguanxue jichu (The Basics of Chinese Museology), Shanghai: Shanghai, Guji Chubanshe (in Chinese)

Yamaguchi, M. (1991) 'The Poetics of Exhibition in Japanese Culture', in Ivan Karp \& Steven D. Lavine, (eds), Exhibiting Cultures: the Poetics and Politics of Museum Display, 57-67, Washington \& London: Smithsonian Institution Press

Yumoto, K. (1996) Meiji jibutsu kigen jiten (The Dictionary of the Origins of the Arts of the Meiji Period), Tokyo: Hakushobô (in Japanese)

Zhang, H. (1987) Bowuzhi (Natural history), Taipei: Jinfeng (in Chinese)

Zhou, H. (1994) Qingpo Zazhi (Random Notes on Clear Waves), Pekin: Zhonghua Shuji (in Chinese)

\section{*Chang Wan-Chen}

Chang Wan-Chen gained her Ph. D. in Museology at the National Museum of Natural History in France and currently teaches cultural policy and museum studies at the Graduate School of Art Management \& Culture Policy, National Taiwan University of Arts (Taiwan). A board member of the International Committee for Museology (ICOFOM, ICOM) since 2010, she is a regular participant at the international conferences on museums studies. Her main publication is: Lunbowuguanxue (Sur la muséologie). Taipei: Diancang, 2005. Recently, she has undertaken a series of studies on exhibition narrative theory.

Chang Wan-Chen

Associate Professor,

Graduate School of Art Management \& Culture Policy,

National Taiwan University of Arts,

Taiwan

59,Sec. 1,

Daguan Rd.,

Banqiao Dist.,

New Taipei City 22058,

Taiwan (R.O.C.)

Tel: 886-2-22722181 ext. 2703

FAX: 886-2-29687563

Email:wanchen@ntua.edu.tw 